\title{
Matters of judicial practice of Sevastopol and the Republic of Crimea in the field of merchant shipping
}

\author{
Stanislav Aleksandrovich Vasiliev* \\ Sevastopol State University, Institute of Law, Department of Constitutional and Administrative Law, \\ Sevastopol, Russia
}

\begin{abstract}
Merchant shipping is one of the most demanded types of transportation in the modern world. According to some reports, up to $80 \%$ of all cargo is transported by sea. In this regard, the issues of legal regulation of this complex and full of implementation nuances activity acquire particular importance. The specific condition of such seaports as Sevastopol and several other ports on the Crimean Peninsula is since Russia is under the influence of negative economic measures ("sanctions") imposed by a large number of foreign states. Under these conditions, with the same effect of international and Russian legislation in the entire territory of the Russian Federation, the nature of their application in some cases has a certain specificity concerning these territories. In this regard, the analysis of judicial practice in this area was of particular interest. The purpose of this study is to analyze judicial practice from the point of view of the implementation of international and Russian law norms in the field of merchant shipping, as well as to identify certain trends in the activities of the subjects of the relevant legal relations. Analysis, synthesis, the comparative method, and the method of expert assessments are the methods used in the preparation of this work. The following structural analysis of the available material was used: first, the judicial practice was studied, only after that the work with legislation and other sources was carried out. As a result of the performed research, some problematic aspects of the legal regulation of merchant shipping in Russia have been identified. The trends based on which the Russian maritime law can be transformed have also been identified. The novelty of the research lies in the combination of proposals for further improvement and law enforcement practice in the field of merchant shipping.
\end{abstract}

Keywords: merchant shipping; the port of Sevastopol; judicial practice; type of vessel

\section{Introduction}

Analysis of the existing judicial practice has shown that, in general, public relations regulated by the law of the sea strive to ensure the rule of law and order, to satisfy the interests of the

\footnotetext{
*Corresponding author: mnogoslov@mail.ru
} 
participants in these legal relations. At the same time, in the process of conducting the research, the emphasis at this stage was placed on the participation of subjects in one or another way related to the city of Sevastopol or the Republic of Crimea, which showed another important legal aspect: when making their decisions, judges mainly refer to Russian legislation, leaving international maritime legal regulation without attention [1-3].

\section{Results}

The main results of the study are the establishment of the main trends in the development of maritime law, based on the transformation of public relations in this area. New technologies emerge in the shipbuilding and operation of this type of transport, which naturally affects law enforcement practice. Besides, the main problems of the application of international law of the sea in the territory of the city of Sevastopol and the Republic of Crimea are outlined. The procedure for the application of public law to resolve property and other private legal relations has been assessed.

\section{Discussion}

The Decision of the Arbitration Court of the Republic of Crimea dated November 27, 2018, indicates that the type of sea vessel is of great importance, which presupposes the presence of certain documents on board. According to Art. 25 of the Merchant Shipping Code of the Russian Federation of April 30, 1999, No. 81-FZ a passenger certificate is included in the list of documents for a passenger ship subject to state registration [4].

In the development of this legislative norm, paragraph 1.4 of the Rules for the Application of Port Dues No. 522-t/1 indicates that it is the ship documents that determine its specialization [5].

Deviation from these requirements is fraught with troubles for shipowners. In particular, the captain of the "Sevastopol" ship, which is a passenger ship, was liable for unjustified enrichment, which was due to the inappropriate use of the vehicle [6]. At the same time, scientists note that the improvement of ship transport technologies, the development of the tourism business, the formation of new products in this area [7] lead to the fact that this formal approach can be detrimental to economic development. The system of classification and subsequent registration of sea or river vessels should become more flexible as time goes and due to ongoing objective processes. Of course, all technical characteristics must ensure safety $[8,9]$, first of all, of people and cargo.

The quality of the provision of sea transportation services must comply with the minimum established legal requirements. It is important to ensure the targeted use of ships, with the help of which certain services are rendered. Vessels are subdivided into cargo and passenger and registered accordingly, after which they must be used for their intended purpose. Deviation from this rule leads to the application of penalties against violators.

Similar requirements are also imposed on the locations of ships. Thus, the Administration of the Black Sea seaports in the city of Sevastopol sent a notification that the floating dock PD-6 could not be allowed for operation due to the lack of necessary documents [10], which limited the economic activity and normal use of this facility.

The provision of all sorts of services in the field of merchant shipping must meet a fairly large number of requirements. At the same time, the persons participating in these legal relations must consider a huge array of normative legal regulations in various branches of law, including international [11], civil, administrative, and even criminal. Also, it is necessary to understand the procedural legislation, which is also heterogeneous. It will be 
shown by the example of the decision of the Arbitration Court of the Nizhny Novgorod Region of September 7, 2015.

According to the materials of the case, the vessel, making the shift from the port of Novorossiysk to the port of Sevastopol, for merchant shipping repeatedly crossed the state border of the Russian Federation to exit and enter without notifying the border authorities and transferring the necessary information to them [12]. Historically, this issue has received the most serious attention [13].

This decision shows that it is necessary to pay attention to compliance with other requirements related to other industry legislation when implementing civil law relations and the activities aimed at providing services under a contract. Although the ship, in this case, had a Russian home port and provided transportation services to satisfy the interests of persons operating within the state, it still, possibly unintentionally [14, 15], violated the provisions of the administrative law, for which it was punished. In this case, it should be noted that regardless of the nature of the main activity and the full fulfillment of the terms of contractual relations, all other requirements related to navigation, in general, should be borne in mind.

This precedent draws attention to itself in the part that the decision for an administrative case was made by an arbitration court authorized to resolve economic disputes [16]. This practice is spreading in Russia, but at the same time, it introduces a certain amount of confusion in the procedures for resolving disputes and the procedure for implementing law enforcement activities. Although not all decisions of arbitration courts go beyond their competence.

For example, by the Decision of the Arbitration Court of the Rostov Region dated December 28, 2017, it was established that LLC UK Reka-More carried out improperly formalized cabotage transportation [17], for which the responsible persons were punished.

This court decision is aimed at resolving a civil dispute $[18,19]$, the essence of which is that in the process of providing sea transportation services, the damage was caused to the cargo that was the object of transportation. The court took the side of the client, who collected the material damage received. The described precedent shows the need for the high-quality provision of services of sea transportation of goods, when not only the very fact of movement of goods in a certain way is important, but also the condition of goods as a result of delivery.

The state, together with its institutions, plays a huge role in modern merchant shipping. The following precedent took place several years ago. An additional agreement was concluded between the Sevastopol seaport and Ecosystem-Crimea LLC to the bareboat charter contract, according to which the port was the shipowner and lessor. The law governing the execution of the bareboat charter contract is the law of the Russian Federation. Changes in the amount of the rent have been made, the payment details of the parties have been changed [20].

The state, represented by bodies and subordinate organizations, as well as other participants in legal relations in the field of merchant shipping, can take part in this commercial activity. In this case, the state acts as a public-law entity [21, 22], while its bodies have the rights of a legal entity [23-25] due to being correspondingly registered with tax authorities. Of course, the public authorities are not interested in violating anyone's rights, but they can also act in claims practice from both sides. Within the framework of the considered precedent, state structures had the status of a plaintiff and restored their violated rights, which is also allowed by the current legal regulation.

Often, the relationship of shipowners with the registering government authorities is the object of litigation in the field of merchant shipping.

By the decision of the Arbitration Court of the city of Sevastopol dated October 5, 2016, the applicant was obliged to register 50 small boats, depending on the purpose of their use, in one of the ship registers of the Russian Federation, and the other party was obliged to provide 
a contract for the land of the corresponding dockside. Besides, it was prohibited to operate the defendant's dockage of small boats [26]. Violation of legal norms by the dockage owners is fraught with serious losses for them. In addition to not receiving profits, they have other obligations to maintain the appropriate area at their own expense, which in some cases implies not only compliance with environmental rules $[27,28]$ but also the fulfillment of requirements related to flood control [29], the fulfillment of labor and social obligations to workers [30].

Any sea vessel before providing any services related to maritime transport must be properly registered. Most often, judicial practice indicates a violation of such a requirement, however, in this case, the shipowner managed to defend his rights, which makes it possible to contradict the prevailing opinion that any litigation, one of the parties to which is the state, its bodies or institutions are initially losing for the representatives of the commercial sector [31].

\section{Conclusion}

The considered judicial practice shows the variety of approaches of the law executor to the interpretation of the provisions of the current legislation and international acts. The international law of the sea is substantially limited concerning the subjects associated with the city of Sevastopol and the Republic of Crimea since persons affiliated with these regions are deprived of the opportunity to carry out international economic activity due to the application of "sanctions" against Russia by a large number of foreign states. At the same time, domestic Russian legal regulation complies with the norms of international law. It was not possible to identify any deviations from this rule in the process of researching judicial practice. Also, the practice of the courts' application of the norms of the maritime law is considered and shows an integrated approach to solving each case, the legal relationship of which affects a large number of various spheres of public life, equally regulated by the norms of public and private law.

The current scientific work was carried out within the framework of an internal grant from the Federal State Autonomous Educational Institution of Higher Education "Sevastopol State University". Project No. 26/06-31 "Legal regulation of financial, property and organizational relations in the field of merchant shipping".

\section{References}

1. K.D. Zinchenko, Diary of Science, 5(41), 77 (2020)

2. V.N. Koval (ed.), Mezhdunarodnoe morskoe pravo (chastnoe i publichnoe): uchebnik [The international law of the sea (private and public): textbook] (Vuzovskii uchebnik, Infra-M, Moscow, 2017)

3. R.R. Novokshchenov, A.K. Volkova, Tribune of the Scientist, 1, 240-246 (2020)

4. Collection of Legislation of the Russian Federation, 18, Item 2207 (1999, May 3)

5. Rossiiskaia gazeta, 294 (2007, December 29)

6. Reshenie Arbitrazhnogo suda Respubliki Krym ot 27.11.2018 po delu N A8316744/2017 [The Decision of the Arbitration Court of the Republic of Crimea in case No. A83-16744/2017] (2018, November 27)

7. A. Egorov, G. Egorov, I. Ilnitskiy, Lect. Notes Civ. Eng. 65, 120-136 (2021). https://doi.org/10.1007/978-981-15-4680-8_9

8. J. Tilander, M. Patey, S. Hirdaris, J. Mar. Sci. Eng. 8(7), 492 (2020). https://doi.org/10.3390/jmse8070492 
9. K. Prill, C. Behrendt, M. Szczepanek, I. Michalska-Pozoga, Energies, 13(5), 1082 (2020). https://doi.org/10.3390/jmse8070492

10. Reshenie Arbitrazhnogo suda goroda Sevastopolia ot 13.10 .2016 po delu N A841413/2016 [The Decision of the Arbitration Court of the City of Sevastopol in case No. A84-1413/2016] (2016, October 13)

11. The Law of the Sea: Rights of access of land-locked states to and from the sea and freedom of transit: Legislative history of Pt. X, Articles 124 to 132 of the UN Convention on the Law of the Sea (UN, Office of the Special Representative of the Secretary-General for the Law of the Sea, New York, 1987)

12. Reshenie Arbitrazhnogo suda Nizhegorodskoi oblasti ot 07.09.2015 po delu N A439087/2015 [The Decision of the Arbitration Court of the Nizhny Novgorod Region in case No. A43-9087/2015] (2015, September 7)

13. G. Carrasco González, Studia Historica, Historia Moderna, 42(1), 165-193 (2020). https://doi.org/10.14201/shhmo2020421165193

14. V.M. Grinyak, S.S. Pashin, The Territory of New Opportunities. The Herald of the Vladivostok State University of Economics and Service, 11(2), 102-112 (2019). https://doi.org/10.24866/VVSU/2073-3984/2019-2/102-112

15. B.N. Ivanov, Vologda Readings, 78, 202-206 (2010)

16. A.V. Semenov, State and Law, 10, 108-110 (2004)

17. Reshenie Arbitrazhnogo suda Rostovskoi oblasti ot 28.12.2017 po delu N A5330939/2017 [The Decision of the Arbitration Court of the Rostov Region in case No. A53-30939/2017] (2017, December 28)

18. T.N. Ivanova, Jurist, 9, 19-24 (2012)

19. S.S. Pavlov, Morskoy Vestnik, 1(41), 96-98 (2012)

20. Reshenie Arbitrazhnogo suda Respubliki Krym ot 15.04.2019 po delu № A8316970/2018 [The Decision of the Arbitration Court of the Republic of Crimea in case No. A83-16970/2018] (2019, April 15)

21. P.V. Krasheninnikov, Publichno-pravovye obrazovaniia v chastnom prave: postateinyi kommentarii glavy 5 Grazhdanskogo kodeksa Rossiiskoi Federatsii: k 15-letiiu vstupleniia v silu chasti pervoi Grazhdanskogo kodeksa Rossiiskoi Federatsii [Public law formations in private law: an article-by-article commentary on Chapter 5 of the Civil Code of the Russian Federation: on the 15th anniversary of the entry into force of part one of the Civil Code of the Russian Federation] (Statut, Moscow, 2010)

22. V.E. Chirkin, Publichno-pravovoe obrazovanie [Public law education] (Norma, Moscow, 2011)

23. S. Zinchenko, V. Galov, Business and Law, 10(357), 102-109 (2006)

24. M.A. Chelyadina, Modern Research Bulletin, 1.9(28), 122-126 (2019)

25. A.V. Shmeleva, Sciff. Issues of Students' Science, 5-2(33), 9-11 (2019)

26. Reshenie Arbitrazhnogo suda goroda Sevastopolia ot 05.10 .2016 po delu N A842331/2016 [The Decision of the Arbitration Court of the City of Sevastopol in case No. A84-2331/2016] (2016, October 5)

27. C. Ji, M.M. El-Halwagi, Ocean Eng. 218, 108241 (2020). https://doi.org/10.1016/j.oceaneng.2020.108241

28. T. Notteboom, L. van der Lugt, N. van Saase, S. Sel, K. Neyens, Sustainability (Switzerland), 12(4), 1688 (2020). https://doi.org/10.3390/su12041688 
29. B. Restemeyer, M. Van Den Brink, J. Woltjer, Planning Practice and Research, 34(1), 62-83 (2019). https://doi.org/10.1080/02697459.2018.1546918

30. C.S. Rebolledo, Avances del Cesor, 16(21), 161-174 (2019). https://doi.org/10.35305/ac.v16i21.997

31. R.M. Zhemaletdinov, Sudebnyi poriadok uregulirovaniia sporov, voznikaiushchikh iz otnoshenii gosudarstva i investora [Judicial procedure for the settlement of disputes arising from relations between the state and the investor], in Ispolnitelnoe proizvodstvo: problemy i zakonodatelstvo. Materialy kruglogo stola [Enforcement proceedings: problems and legislation. Roundtable materials], pp. 59-68 (Bashkir State University, Ufa, 2016) 